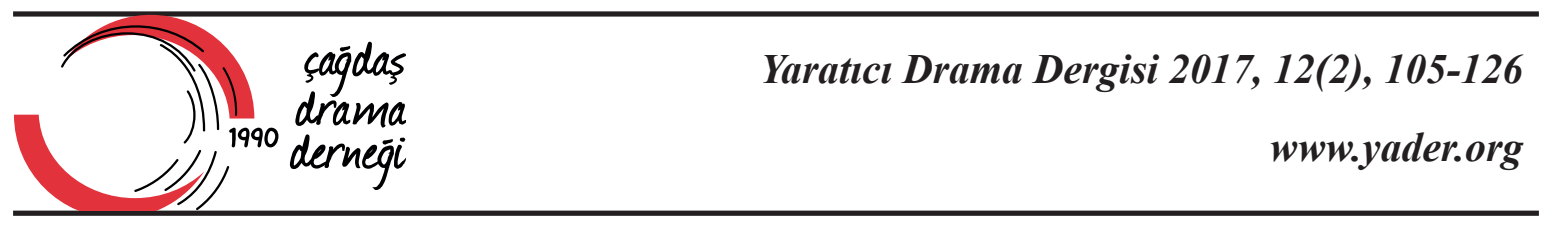

\title{
Müzelerde ve Arkeolojik Alanlarda Drama Uygulamaları
}

\author{
Ali Akın Akyol ${ }^{1}$
}

Aysel Köksal Akyol ${ }^{2}$

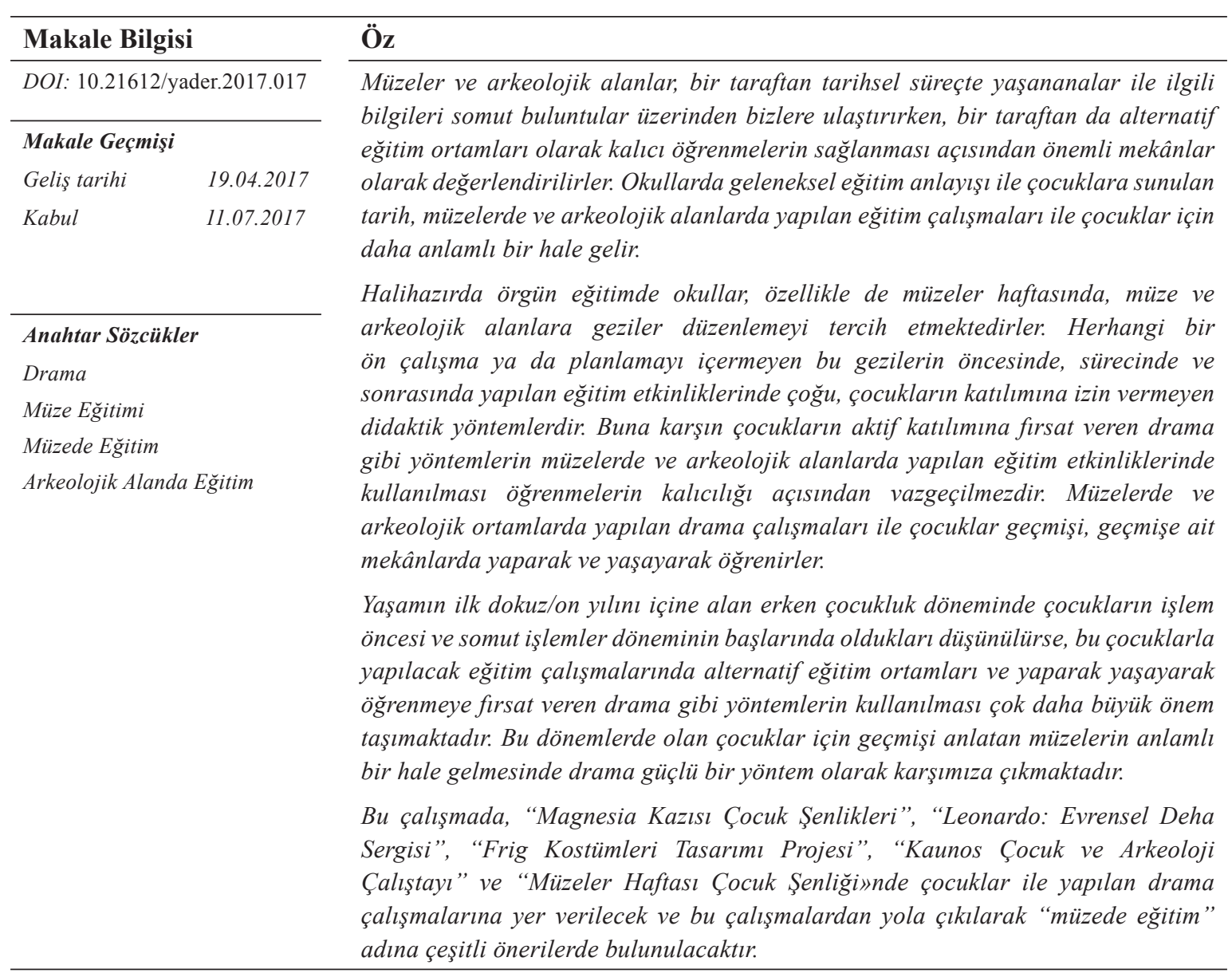

Gazi Üniversitesi, Güzel Sanatlar Fakültesi, Kültür Varlıklarını Koruma ve Onarım Bölümü

2 Ankara Üniversitesi, Sağlık Bilimleri Fakültesi, Çocuk Gelişimi Bölümü 


\section{Drama Practices in Museums and Archaeological Sites}

\begin{tabular}{ll} 
Article Info \\
\hline DOI: $10.21612 /$ yader.2017.017 \\
\hline & \\
\hline Article History & \\
Received & 19.04 .2017 \\
Accepted & 11.07 .2017
\end{tabular}

Keywords

Drama

Museum Education

Education in Museums

Education at Archaeological Sites

\begin{abstract}
While the museums and archaeological sites convey the information about historical events to us through concrete finds from one side and from the other side, they are considered as important places in terms of providing permanent learning as alternative educational environments. The history presented to children with the traditional education approach in the schools becomes more meaningful for children with educations made in museums and archaeological sites.
\end{abstract}

At present, schools in structured education prefer to organize trips to museums and archaeological sites, especially at museum weeks. Many of the educational activities that took place before, during and after these trips that did not involve any preliminary work or planning were didactic methods that did not allow children to participate. On the other hand, the use of methods such as drama, which gives children active participation in education activities in museums and archaeological sites, is indispensable in terms of the permanence of learning. Through drama studies in museums and archaeological sites, children learn by making and living "in the past", "in the places of the past".

If children are thought to be in the early stages of pre-operational and concrete operational in early childhood, which includes the first nine to ten years of life, it is of utmost importance to use alternative methods of education in these educational activities, such as drama. For children in these periods, drama has emerged as a powerful method as the historical narrators become meaningful.

In this work, the drama studies with the children will be given in the "Magnesia Excavation Children's Festival", "Leonardo: Universal Genius Exhibition", "Phrygian Costume Design Project", "Kaunos Children and Archaeology Workshop" and "Museum Week Children's Festival" and various suggestions will be made on the way to "education in the museums".

This study will include drama studies with children in "Magnesia Excavation Children's Festival", "Leonardo: Universal Genius Exhibition”, "Phrygian Costume Design Project", "Kaunos Children and Archaeology Workshop" and "Museum Week Children's Festival" various suggestions will be made on behalf of "museum education”. 


\section{Giriş}

Müzeler ve arkeolojik alanlar geçmişte yaşananlar ile ilgili bilgileri somut buluntular üzerinden bizlere ulaştırır; alternatif eğitim ortamları olarak geçmişi anlamamıza aracılık eder. Ülkemizde müzelerin ve arkeolojik alanların eğitim ortamları olarak kullanılma durumuna baktığımızda; geçmişte hatta günümüzde de, müzelere daha çok okulların düzenlediği kalabalık gruplarla ve kısa sürede yapılan gezilerin olduğunu görürüz. Ancak son yıllarda müze ziyaretçilerinin aktif katılımını sağlayan uygulamalara doğru bir ilerlemenin olduğu dikkati çekmektedir; müzeler mekânlarında eğitim atölyeleri oluşturmakta, okul öncesinden üniversiteye kadar etkili müze gezileri düzenlenmektedirler. Özbek (2016)'in çalışmasında, müzelerin temel görevleri arasında eğitimin de yer almasıyla birlikte müzelerde eğitim ortamları oluşturulduğunu ve bu ortamlarda görev yapmak üzere eğitimciler istihdam edildiğini, müzelerin kendi eğitim programlarını oluşturduklarını belirtmiştir.

Günümüzde, müzeler durağan sergiler içeren depo anlayışı yerine düşündüren, duygulandıran ve aktif hale getiren müze anlayışına doğru ilerlemektedir. Okul dışı mekânlar arasında müzelerin önemli bir yeri vardır. Müzeler, içerdiği koleksiyonlarını sergilemenin çok ötesinde, bilginin paylaş1ldı̆̆ önemli mekânlardan biridir ve özellikle sistematik bilgiye ulaşma konusunda eğitimin laboratuvarı işlevini görür "Müze nasıl algılanıyor?", "İnsanlar müzelerden nasıl etkileniyor?” ya da "Acaba sergiler bireyler için, daha duygulandırıcı, daha anlaşılır ve eğlendirici hale nasıl getirilebilir?" gibi sorulardan yola çıkarak müzelerin etkili eğitim ortamları olarak kullanılması konuları üzerinde durulmaktadır (Paykoç, 2011; Köksal Akyol ve Akyol, 2015).

Eğitimde aktif katılımın ve somut görsel materyallerinin öneminin benimsenmesi ile birlikte müzelerin aktif öğrenme ile ilgili katkılarının keşfedilmesi, eğitim-müze işbirliğini en iyi biçimde açıklayan "müze pedagojisi/müze eğitimi” kavramını ortaya çıkarmıştır (Paykoç ve Baykal, 2000). Müze eğitimi, temel eğitimde ve yaşam boyu eğitim sürecinde yaşantılara dayalı çok yönlü öğrenme ve müzelerin eğitim ortamı olarak etkin kullanımı (Adıgüzel, 2000); toplumun gelişmesi, estetik olgusunun yerleşmesi, yaşanan anın, geçmişin ve giderek geleceğin açıklanması, yorumlanması, toplumsal değişimlerin yönlendirilmesi ve halkın eğlenirken gelişmesi, zamanın değerlendirilmesine yönelik bir eğitim olarak açıklanmaktadır (Atagök, 1982).

19. yüzyılın ortalarında müzelerin işlevlerinden birinin de eğitim olması gerektiği düşüncesi ortaya çıkmıştır. Yirminci yüzyılın başlaması ile müzelerin sayısında artış olmuş ve müzecilik anlayışı değişmiştir. Gelişen eğitim-öğretim teorileri ve müzecilik anlayışı ile birlikte, eğitim ve kültüre katkıda bulunabilmek için müzelerin toplumla daha yakın ilişkiler kurmaların gerekliliği fark edilmiş, bu yönde müzelerde çalışmalara başlanmıştır. Bu süreç ile müzelerin tanımı ve eğitim programları yeniden yapılanmış, müzelerin işlevleri değişmiş ve müzelere yeni görevler eklenmiştir. $\mathrm{Bu}$ değişim süreci ile beraber müze eğitim bilimi doğmuş ve gelişmiştir (Onur, 2008; Buyurgan ve Mercin, 2005; Tezcan Akahmet, 2001). Ülkemizde yüz elli yıllık geçmişi bulunan müzeciliğin, günümüzde geldiği nokta her ne kadar sergilemeden ileriye gidemiyorsa da gerek üniversitelerin eğitim programlarında gerek devlet müzelerinde gerekse özel müzelerde süre gelen yeni gelişmeler, müzelerde daha sistemli eğitim etkinliklerinin başladığını göstermektedir (Akyol 2003; Akyol, vd., 2004; Akyol, 2006; Demirdelen, 2003, s.334; Denizli, vd., 2006; 2007). 
Müze eğitiminin temelinde müzede öğrenme olgusu vardır. Müzelerin koleksiyonları, sergileri, insan kaynakları ve uzmanları ile gerçek bilgi kaynakları olması, bilgiye erişim, bilgiyi kullanma ve paylaşma yönünden bireye farklı bir ortam sunar. Bu da bireylerde üst düzey düşünme becerilerinin ve sosyal becerilerin gelişmesine yardım eder. Ayrıca müzede öğrenme, katılıma, işbirliğine ve bireyin bilgi, beceri ve tutumlar yönünden güçlenmesine yardımcı olur; böylece de yapıcı ve kalıcı öğrenme söz konusu olur (Paykoç, 2011). Müzeler insanlar tarafından üretilen eserlerin farkına varılmasını ve kültürler arası iletişimi sağlar. Aynı zamanda müze, insanlık tarihini nesnelerle sunarken, yaratıcı düşünceye sahip insanların yetişmesine katkıda bulunur (Buyurgan ve Mercin, 2005). Kendi kültürünü ve farklı kültürleri çok yönlü ve hoşgörülü bir yaklaşımla tanıma, benzerlik ve farklılıkları anlama, kültürlerarası anlayış ve empati geliştirme, çevreyi ve kültürel varlıkları koruma bilincini geliştirmede etkili olur. Müze eğitimi, insanın değişen dünyaya ve çevreye uyum sağlamasına yardım eder, geçmişle şimdiki yaşam arasında bağlantı kurar ve geleceğe dönük düşünmeyi, problem çözmeyi sağlar. Eserler ve objelerle insanlar arasında köprü kurarak onların yaşantıları ile bütünleşmesinde etkili olur (Paykoç ve Baykal, 2000; Paykoç, 2011). Müzeler sahip oldukları koleksiyonlar ile bireylerin kendilerini, doğayı, dünyayı tanımalarına yardımcı olur (Fazlıŏ̆lu ve Fazlıoğlu, 2009).

Müzelerin olduğu binalar, mekân ve objeler çocuk için eğitimci görevini üstlenir; çocuklar kitaplardan okuyarak ya da eğitimcinin anlattıklarını dinleyerek öğrenme yerine gerçek mekânlarda ve gerçek objeleri görerek geçmiş ile ilgili bir çok bilgiye ulaşırlar. Artut (2009)'un da ifade ettiği gibi; müzeler, kitapların ve derslerin açıkça ortaya koyamadıklarını objeler aracılığıyla görülebilir kılar. Objelere bakmak, objelerle çalışmak, karşılaştırma yapmak, anımsamak, ilişki kurmak, sınıflandırmak, sorgulamak, somut gözlemlerden soyut kavramlara geçmek, bilinenden bilinmeyene uzanmak, belirgin gözlemlerden genellemelere ulaşmak gibi birçok farklı yöntem ile düşünmenin gerçekleşmesini sağlar. Sınıf ortamında, geleneksel öğretim biçimleri ile zorluklar yaşayan çocuklar, müze ortamında objeler ve çeşitli etkinlikler aracılığıyla daha kolay öğrenirler (Hein, 1998).

Müzeler ve arkeolojik mekânların drama gibi çocukların aktif katılımına firsat veren yöntemlerin kullanılması geçmişi anlamamızda bizlere daha da çok yardımcı olmaktadır. Günümüzde eğitim sistemi yapıcı, yaratıcı, yeniliklere açık, kendini ifade edebilen, analiz ve sentez yeteneğine sahip bireyler yetiştirmeyi hedeflemektedir. Eğitim sistemi içeresinde öğrenmede önemli rol oynayan yöntemlerden birisi de dramadır. Çocukların gerçek dünya ile kurgusal dünya arasında gidip gelmelerini olanaklı kılan dramanın genel amacı: her alanda yaratıcı, kendine yetebilen, kendini tanıyan, çevresiyle iletişim kurabilen ve bunu geliştirebilen, ifade gücü ve biçimleri artmış bireyler yetiştirmektir. Drama; bilişsel davranışları, duyuşsal özellikleri ve devinişsel becerileri kazandırmada bir öğretim yöntemi, başta duyuların eğitimi olmak üzere bütüncül ve estetik anlayış oluşturmada sanat eğitimi alanı ve yaşanılan süreci betimlemede, açıklama ve kontrol edebilme olanaklarıyla bir disiplindir (Kandır 2003, McCaslin 2006, Adıgüzel 2010, Can Yaşar 2013, Dalbudak Pekdemir ve Köksal Akyol, 2015).

Eğitimciler programlarında drama yöntemini kullanarak çocukların gelişimleri ve etkili öğrenmelerini destekleyebilirler. Drama çocuklara düşsel etkinlikler ve deneyimlerle yeni bilgilere ulaşma şansı verir. Bireysel farklılıklar dikkate alındığında her bir çocuğun kendine uygun olan yolla öğrenmesine yardımcı olur. Önceki bilgileri ve deneyimleri de kullanarak yeni bilgilere ulaşır. Çocuğun entelektüel gelişimine destek olur. Sezgisel ve spontan etkinlikler yoluyla yaratıcıllığı 
ve problem çözme becerisi gelişir. Başkalarının duygu ve düşüncelerini anlama ve etkili iletişim becerilerini destekler. Rol alma becerisinin gelişimine paralel olarak artan empatik beceri ile birlikte sosyal ve duygusal gelişim desteklenir (Hendy ve Toon, 2001; Alevcan, 2005; Hui ve Lau, 2006; Wright, 2006; Szecsi, 2008). Çocuklar üzerinde belirtilen olumlu etkilerin sağlamasında; dramaya eğitim programlarında yer veren öğretmenin istenen bilgi ve deneyime sahip olması, çocukların içinde bulundukları gelişim özellikleri, dramaya yönelik birikim ve deneyiminin yeterli olması, eğitim yapılacak müzeler ve arkeolojik alanlar ile ilgili araştırma yapılması ve alan uzmanları ile işbirliği yapmak gerekmektedir (Yetimoğlu ve Akyol, 2013; Köksal Akyol, 2014).

Ülkemizde, çocuklar ile arkeolojik alanlarda ve müzelerde yapılan eğitim etkinlikleri incelendiğinde, sonyıllardaçocuklarınaktifolarakkatıldıklarıçalışmalarınolduğudikkati çekmektedir; 1996 yılından beri düzenlenmekte olan "Magnesia Kazısı Çocuk Şenlikleri”ne ilköğretim çağındaki çocuklarının yanı sıra anaokulu çağında olan çocukların da katıldığı görülmüştür (Bingöl, 2004; Akyol, ve Köksal Akyol, 2005; Bingöl ve Bingöl, 2014). 2002-2008 yılları arasında "Frig Kostümleri Tasarımı Projesi”, "Ankara Roma Hamamı Çocuk Olimpiyatları”, "Müzeler Haftası Çocuk Şenliği”" gibi etkinliklere ve Anadolu Medeniyetleri Müzesi, Ankara Roma Hamamı ve Gordion Müzesi'nde çocuklarla müzede eğitim çalışmalarına özel yer verildiği belirlenmiştir (Akyol ve Alpagut, 2012; Akyol, 2016). 2012 yılında Kaunos'ta gerçekleştirilen “Çocuk ve Arkeoloji Çalıştayı”nda ise çocuklar kazı evinde ve kazı alanında eğitim almışlardır (Çocuk Çalıştayı, 2012). Mardin Müzesi ve Çorum Müzesi'nde de, çocuklarla yapılan eğitim etkinliklerinin olduğu bilinmektedir (Mardin Müzesi, 2010; Çorum Müzesi, 2011). Çocukların aktif katılımların olduğu bu çalışmaların yanı sıra "Senden Önce Anadolu Projesi Eğitim Kitapları" ile çocuklara Anadolu Uygarlıkları ilgi çekici bir şekilde sunulmuştur (Akyol vd., 2012). Çoğunlukla okul çağ çocukları, zaman zaman da okul öncesi dönem çocukları ile yapılan bu çalışmaların artmasına rağmen, kapsam, içerik ve sıklık açısından ise yetersiz olduğu görülmektedir (Köksal Akyol ve Akyol, 2014). Müzelerde ve arkeolojik alanlarda yapılan çalışmaların çocuklar üzerinde sağladığı yararlar dikkate alındığında, benzer çalışmaların daha da yaygınlaşmasının gerekli olduğu söylenebilir (Akyol vd., 2015).

Müzelerde ve arkeolojik alanlarda, özellikle de yaparak yaşayarak öğrenmenin söz konusu olduğu drama yöntemiyle yapılan eğitim etkinliklerinin önemli olduğu görüşünden yola çıkarak, bu çalışmada müze ve arkeolojik alanlarda çocuklara yönelik yapılmış olan bazı çalışmalara ve bu çalışmalarda uygulanmış olan drama çalışmalarına yer verilecektir.

\section{Müzelerde ve Arkeolojik Alanlarda Drama Uygulamaları}

Ülkemizde müzelerde çocuklarla yapılan eğitim çalışmalarının giderek yaygınlaştığı görülmekle birlikte, arkeolojik alanlarda ve "Leonardo: Evrensel Deha Sergisi"nde olduğu gibi tarihin sayfalarından bizlere ulaşan sergi organizasyonlarında yapılan çalışmaların çok daha az olduğu dikkati çekmektedir. Müze eğitimlerinde, drama gibi yaparak yaşayarak öğrenme firsatı sunan yöntemlere yer verilmekte, ancak hem müze eğitimlerinde hem de müzelerde yapılan drama çalışmalarında erken çocukluk döneminde olan çocuklara yönelik planlamaların sınırlı olduğu bilinmektedir.

Bu çalışmada "Müzeler Haftası Çocuk Şenliği”, "Magnesia Kazısı Çocuk Şenlikleri”, "Leonardo: Evrensel Deha Sergisi”, "Frig Kostümleri Tasarımı Projesi” ve "Kaunos Çocuk ve Arkeoloji Çalıştayı” kapsamında çocuklarla yapılan drama çalışmalarından örnekler sunulmaktadır. 


\section{Anadolu Medeniyetleri Müzesi Müzeler Haftası Çocuk Şenliği}

Anadolu Medeniyetleri Müzesi’nde müze eğitimi etkinlikleri kapsamında çocuk şenliklerinin yapılmasına karar verilmiştir. Müzeler Haftasının çocuklar tarafından daha hoşa gitmesi ve etkinliklerde çocukların da yer alması düşüncesinden yola çıkılarak ilk kez 2003 yılında Müzeler Haftası kutlamaları çerçevesinde "Çocuk Şenlikleri” düzenlenmiştir. Anadolu Medeniyetleri Müzesi Müdürlüğü ile birlikte Müzeciler Derneği ve Çatı Çocuk Kültürü Grubu'nun da zaman zaman organizasyonda yer aldığı Anadolu Medeniyetleri Müzesi Çocuk Şenlikleri hazırlık çalışmalarında şenliğe katılacak okullar, yapılacak etkinlikler, görev alacak gönüllü görevliler belirlenmiş ve öncesinde belirlenen okullardan gelen çocuklarla etkinlikler müzenin bahçesi, müze binasının içinde farklı mekânlar ve eğitim atölyesinde gerçekleştirilmiştir. Yapılan etkinliklerden bir tanesi de çocuklarla yapılan drama çalışmasıdır. Burada ilkokul çocukları ile yapılmış olan bir drama çalışmasına yer verilmiştir.

\section{Drama Çalışması}

Grup: İkinci sınıfa devam eden çocuklar

\section{Kazanımlar:}

Müze hakkında fikir sahibi olur.

Müze ile ilgili izlenimlerini paylaşır.

Müzedeki eserlerden yararlanarak görsel tasarımlar yapar.

Materyaller: Büyük karton, kağıt, pastel boya, Çatalhöyük evi ile ilgili resimlerin olduğu kartlar

\section{Öğrenme süreci:}

\section{Isınma calısmaları}

$\checkmark$ Çocuklar müzeye gelmeden okulda yaptıkları müze ile ilgili resimlerini birbirlerine gösterirler.

$\checkmark$ Çocuklarla birlikte müzedeki Çatalhöyük evi önüne gelinir. Eğitimci çocuklara "Burası bir ev, bu evde nelerin olduğunu inceleyip bir tanesini seçin, seçtiğiniz şeyi bize hareketlerinizle anlatın" der. Çocuklar belirledikleri nesneleri bedenleri ile sergilerler.

$\checkmark$ Çocuklar "Sizce bu evde kimler yaşamış olabilir?", "Acaba bu kişiler bu evde neler yapmış olabilirler?", "Bu evde çocuklar hangi oyunları oynamış olabilir?” vb sorular hakkındaki düşüncelerini söylerler. Çocukların oynamış olabilecekleri bir oyunu hep birlikte oynarlar.

$\checkmark \quad$ Üç farklı duvar resminden hazırlanmış küçük kartlar çocuklara dağıtılır (Şekil 1). Küçük kartlar her bir resimden eşit olacak şekilde hazırlanır. Çocuklar ellerindeki kartlara göre gruplara ayrılmış olur. Her grup elindeki kartlardaki resimleri inceler. Ellerindeki kartta olan resimden esinlenerek grup olarak heykel olurlar (Şekil 2). 


\section{Canlandirma}

$\checkmark \quad$ Lider müze çalışanı rolüne girerek çocuklara "Müzemizin Çatalhöyük evine ait bazı eserler kaybolmuş, bu eserleri nasıl bulabiliriz?” der. Çocuklardan gelen öneriler tartış1lır. Lider kaybolan eserlerin resimlerinin olduğu kartlardan iki çocuğa bir kart vererek dağıtır, resimlerin eşlerini de müzenin bazı yerlerine koyar. Çocuklar buldukları resimleri getirirler.

$\checkmark$ Gruplar oluşturulur. Eğitimci çocuklara büyük bir karton ve boya malzemeler verir, çocuklardan buldukları resimleri kartona yapıştırıp etrafını tamamlamalarını ister (Şekil 3). Tüm çocukların çizim yapmalarına firsat verilir. Çocukların resim yapmaları bittikten sonra resimde olanlar hakkında konuşulur. Yapılan bu resimden yola çıkarak bir öykü oluşturulur. Oluşturulan öykünün dramatizastonu yapılır.

$\checkmark$ Gruplar canlandırmalarını yaptıktan sonra eğitimci grupların oluşturdukları öyküleri birleştirerek yeni bir öykü oluşturmalarını söyler. Tüm çocukların katılımı ile yeni bir öykü oluşturulur. Oluşturulan öykünün başlangıcı ve sonucu ile ilgili fotoğraf kareleri oluşturulur. Fotoğraf karesi ile başlayıp biten tüm grubun katılımı ile doğaçlama yapilir.

\section{Değerlendirme}

$\checkmark$ Çocuklarla drama sürecinde yaşanılanlar hakkında konuşulur; "müzede neler gördükleri, neler yapmaktan hoşlandıkları” hakkında sohbet edilir. Çocuklar okula gittiklerinde tekrar müze ile ilgili resim yaparlar. Daha önce yaptıkları resimler ile gezi sonrasında yaptıkları resimleri karşılaştırırlar (Şekil 4).
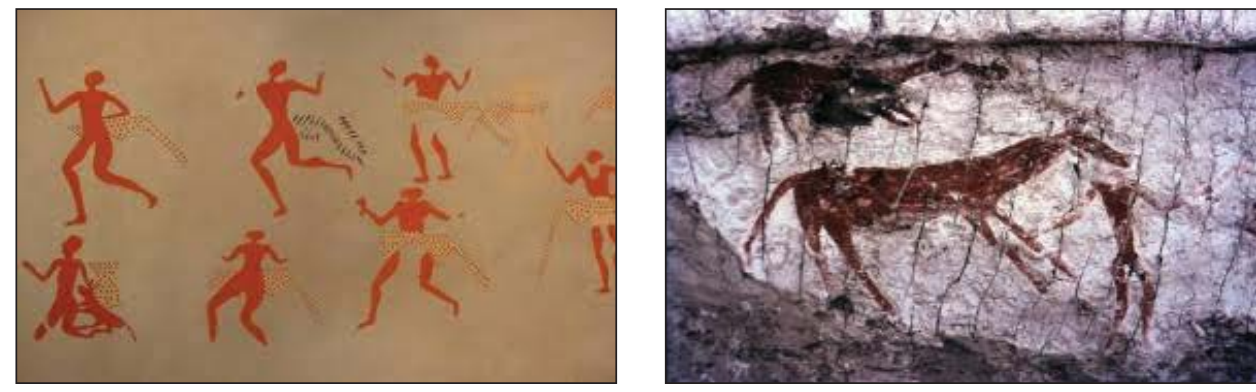

Şekil 1. Kartlarda olan duvar resimleri

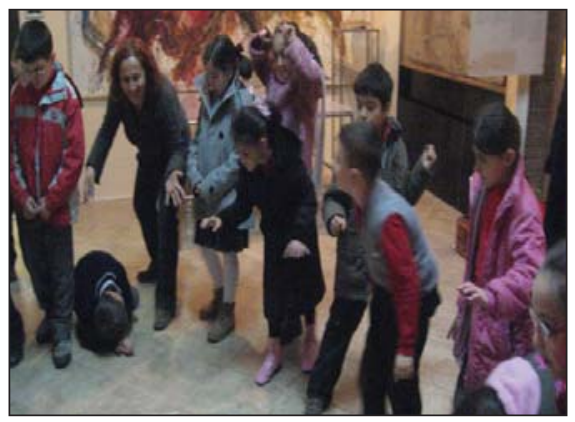

Şekil 2. Isınma çalışmaları 


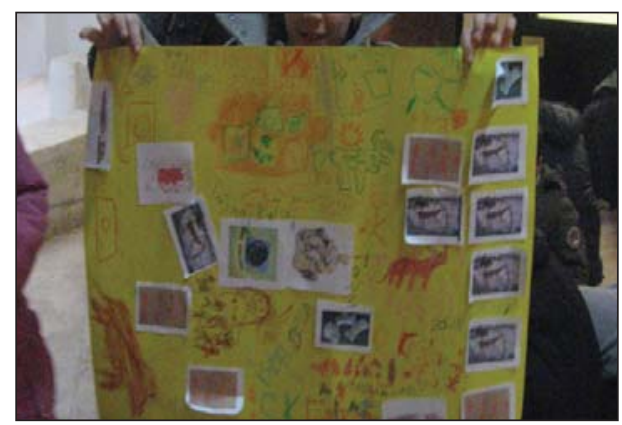

Şekil 3. Gruplar tarafindan yapılan kolaj ve resim çalışması
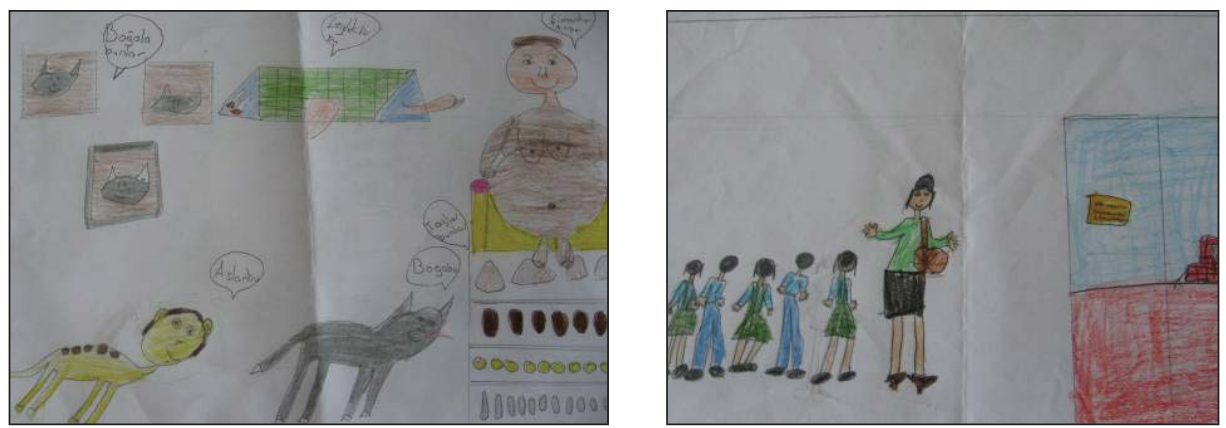

Şekil 4. Müze öncesi ve sonrasında yapılan resimler

\section{Magnesia Kazısı Çocuk Şenlikleri}

Magnesia antik kenti, Aydın ili, Germencik İlçesi, Ortaklar bucağına bağlı, Tekinköy sınırları içinde, Ortaklar-Söke yolu üzerindedir. Magnesia çevresi surlarla kaplı, Priene, Efes, Tralles arkeolojik kazılarının oluşturduğu üçgen arasında ticari ve stratejik açıdan önemli bir konuma sahip olan antik kenttir. Magnesia'da, 1996 yılından itibaren Magnesia Kazısı Çocuk Şenlikleri düzenlenmektedir. 16-18 Ağustos 2004 tarihlerinde, Magnesia Kazısı Çocuk Şenlikleri kapsamında 4-16 yaşlarında toplam 31 çocukla drama uygulamaları yapılmıştır. 4-6 yaşlarında olan çocuklar ve 6 yaş üstünde olan çocuklar için drama süreçleri ayrı planlanmış olmakla birlikte çocukların tümünün katıldığı çalışmalara da yer verilmiştir. Çalışmalar kazı evi olarak kullanılan eski ilkokul binasının bahçesinde başlanmış, Magnesia kazı alanında devam edilmiştir (Şekil 5). Bu çalışmada, Magnesia Kazısı Çocuk Şenlikleri'nde uygulanan örnek iki çalışmaya yer verilmiştir. 


\section{Drama çalışması}

Grup: Okul öncesi dönemde olan çocuklar

\section{Kazanım ve Göstergeler:}

\section{Bilişsel Gelişim:}

Kazanım: Nesne/durum/olaya dikkatini verir. (Göstergeleri: Dikkat edilmesi gereken nesne) durum/olaya odaklanır. Dikkatini çeken nesne/durum/olayı ayrıntılarıyla açıklar.)

\section{Dil Gelişimi:}

Kazanım: Dinlediklerinin/izlediklerinin anlamını kavrar.

(Göstergeleri: Dinlediklerini/izlediklerini açıklar.)

\section{Sosyal ve Duygusal Gelişim:}

Kazanım: Kendini yaratıcı yollarla ifade eder.

(Göstergeleri: Duygu, düşünce ve hayallerini özgün yollarla ifade eder.)

Malzemeler: Origamiden yapılmış kalpler, bant, nazar boncukları, çatal iğneler, pastel boyalar

\section{Isınma Calıșmalart}

$\checkmark$ Çocuklar origamiden yapılmış kalpleri alırlar. Eğitimci çocukların aldıkları kalplerin üzerine adlarını yazıp çatal iğne ile giysilerine takar.

$\checkmark$ Çocuklar adlarındaki hece sayısı kadar hareket bularak bu hareketlerle adlarını söylerler.

$\checkmark$ Elektrik oyunu basitten zora doğru, önce el çırparak, sonra elleri sıkarak oynanır.

\section{Canlandırma}

$\checkmark$ Çocuklar "Köyünüzde neler var?", "Bu kazı evindeki insanlar neden buraya gelmişler?”, "Magnesia kazı alanına gittiniz mi?”, “Kazı alanında neler var?”, "Magnesia kazı alanında evler bulunmuş, bu evlerde kimler yaşamış olabilir?", “Çocuklar oyun oynuyorlar mıydı?", "Kadınlar, erkekler neler yapıyorlardı?” gibi sorular1 yanitlarlar.

$\checkmark$ Eğitimci “Şimdi burada gördüğünüz alan Magnesia'da yaşamış bir ailenin evi. Acaba bu evde kimler yaşıyor, bu evde neler var. Resimlerini çizip istediğiniz yere koyabilirsiniz" yönergesi verir. Çocuklar yaptıkları resimleri istedikleri yerlere kayarlar. Çocuklar resimlerini yaptıkları kişiler ya da objelerin heykeli olurlar. Yapılan heykeller incelenir, heykelini ne olduğu tahmin edilmeye çalışılır.

$\checkmark$ Yapılan resimler gruplardaki çocuklar tarafindan incelenir ve resimlerde neler olduğunu söylerler. Oluşturdukları ev ile şu anda köylerindeki ev ile benzerlikleri ve farklılıkları belirlerler. Benzerliklere ve farklılıklara yönelik fotoğraf kareleri oluştururlar. Fotoğraf kareleri sırası ile incelenir, benzerlikler ve farklılıklar ortaya konmaya çalış1lır. 
$\checkmark$ Çocuklar yaptıkları resimlerden yola çıkarak Magnesia dönemi ile ilgili bir öykü oluştururlar. Oluşturulan öyküyü canlandırırlar.

\section{Değerlendirme}

$\checkmark \quad$ Lider ve gönüllü çocuklardan biri ile elleri yukarıda birleştirerek bir gökkuşağı oluşturur. Çocuklar gökkuşağının altından geçerken drama sürecinde yaşanılanlar ve Magnesia ile ilgili sorulan sorulara yanıt verirler; lider "Drama sürecinde yapılan şeylerden bir tanesini söyle?", "En çok neyi yapmaktan hoşlandın?”, "Hoşlanmadığın birşey oldu mu? Ne oldu?", "Magnesia kazı evinde olan birşey söyle? gibi soruları sorar, güneşi oluşturan çocuk da kendi belirlediği soruları sorar.

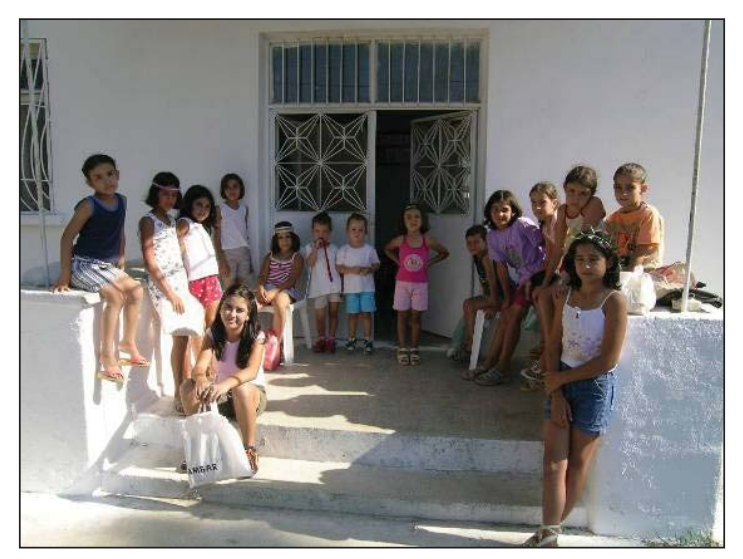

Şekil 5. Magnesia kazıevi önünde buluşma

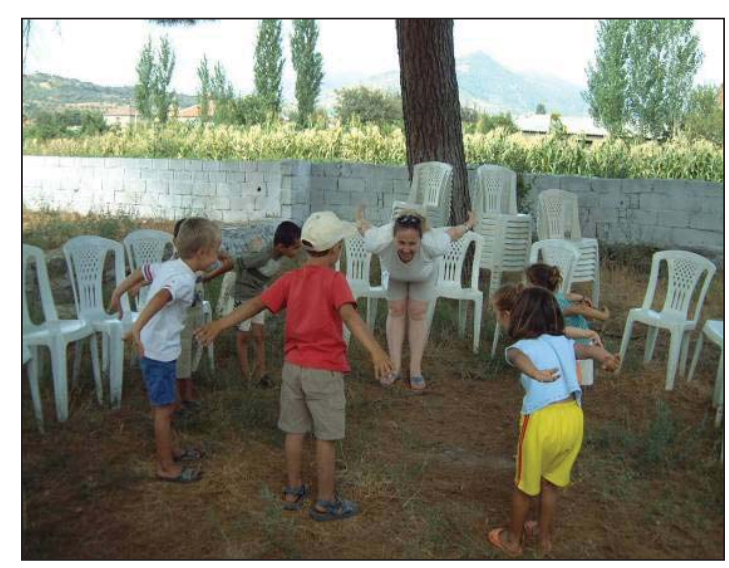

Şekil 6. Isınma çalışmaları 


\section{Drama Çalışması}

Grup: İlköğretime devam eden çocuklar

\section{Kazanımlar:}

Ören yeri, tarihî eser, anıt vb. hakkında fikir sahibi olur.

Yakın çevresinde bulunan ören yerinin geçmişi hakkında ön bilgi edinir.

Ören yeri ile ilgili ile ilgili izlenimlerini paylaşır.

Malzemeler: Pastel boya kutusu, kozalak, taş, çam ağacığı kabuğu

\section{$\underline{\text { Isınma Calısmalart }}$}

$\checkmark \quad$ "Liderin yaptığını yap" oyunu oynanır. Gönüllü olarak lider olan çocuklarla oyuna devam edilir (Şekil 6).

$\checkmark$ Çocuklardan gönüllü olanlar sırası ile ortaya konmuş olan pastel boya kutusu, kozalak, taş, çam ağacı̆̆ı kabuğunu mekândaki konumlarına göre inceleyip bir ağacın arkasına geçerler. Diğer çocuklar materyallerin yerinde değişiklik yaparlar. Ağacın arkasına giden çocuk gelip materyallerin konumlarındaki değişikleri bulmaya çalışırlar.

$\checkmark$ Çocuklarla "kazı alanına en son ne zaman gittikleri, neler gördükleri, geçen senelere göre kazı alanında ne gibi farklılıkların olduğu” gibi konular hakkında konuşulur.

\section{Canlandirma}

$\checkmark \quad$ Lider "Kazı alanında yer alan antik tiyatronun bilinmeyen bir nedenden dolayı yapımının bitirilememiş olduğu söyler. Neden tiyatronun inşaatının yarım kalmış olabileceği ile ilgili çocuklar görüşlerini söylerler.

$\checkmark$ Gruplara ayrılan çocuklar bu tiyatronun yapım aşamasında neler olmuş olabileceği, eğer o dönemlerde yaşasalardı tiyatronun yapımı için neler yapabileceğini üzerine yoğunlaşıp doğaçlamalarını yaparlar (Şekil 7). Doğaçlamalarını fotoğraf karesi ile başlatıp fotoğraf karesi ile bitirirler.

\section{Değerlendirme}

$\checkmark$ Çocuklar süreçte yaşadıkları hakkında konuşurlar. Bir gün sonra antik tiyatroya gidildiğinde, orada neler yapılabileceği hakkında beyin firtınası yapılır.
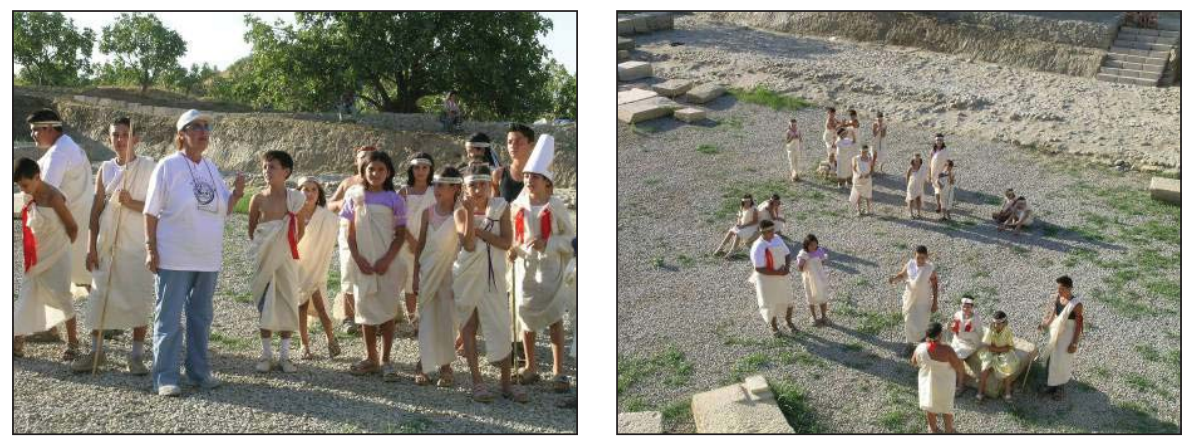

Şekil 7. Kazı alanındaki antik tiyatroda yapılan doğaçlama çalışması 


\section{Leonardo: Evrensel Deha Sergisi}

ODTÜ’nün ev sahipliği yaptığı “Leonardo: Evrensel Deha” sergisi 24 Şubat-24 Mart 2007 tarihleri arasında yapılmıştır. Bu sergide, Leonardo da Vinci'nin 1478-1513 yılları arasında tasarladığ 1 orijinal çizimlerinden yola çıkarak konularında uzmanlaşmış tarihçiler ve mühendisler tarafından inşa edilmiş benzersiz 40 adet işlevsel, çoğu gerçek ebatlarda olan replikalar yer almıştır. Leonardo da Vinci'ye eserlerinde ilham veren doğanın dört elemanı "Toprak", "Ateş", "Hava" ve "Su"ya göre tasarlanmış replikalar ile Leonardo da Vinci'nin tasarladığ diğer mekânizmalar beş ayrı bölümde sergilenmiştir. Ziyaretçiler, interaktif olarak hazırlanan sergide bazı makinelere dokunabilme ve hatta kullanabilme imkanına sahip olmuşlardır. Sergide okul öncesi, ilköğretim ve ortaöğretim kurumlarının randevu alarak gelmesi ile çocukların sergiyi drama yöntemi ile gezmelerine de firsat verilmiştir. Uygulanan drama çalışmalarına aşağıda yer verilmiştir.

\section{Drama Çalışması}

Grup: Okulöncesi, birinci ve ikinci sınıfa devam eden çocuklar

\section{Okul öncesi dönem çocukları için kazanım ve göstergeler:}

\section{Bilişsel Gelişim}

Kazanım: Nesne/durum/olaya dikkatini verir.

(Göstergeleri: Dikkat edilmesi gereken nesne/durum/olaya odaklanır. Dikkatini çeken nesnel durum/olayı ayrıntılarıyla açıklar.)

Kazanım: Nesne ya da varlıkları özelliklerine göre eşleştirir.

(Göstergeleri: Nesne/varlıkları birebir eşleştirir.)

Kazanım: Problem durumlarına çözüm üretir.

(Göstergeleri: Probleme çeşitli çözüm yolları önerir. Çözüm yollarından birini seçer.)

\section{Sosyal ve Duygusal Gelişim}

Kazanım: Kendini yaratıcı yollarla ifade eder.

(Göstergeleri: Duygu, düşünce ve hayallerini özgün yollarla ifade eder. Özgün özellikler taşıyan ürünler oluşturur.)

\section{Birinci-İkinci Sınıfa Devam Eden Çocuklar için Kazanımlar:}

Sanat sergisi ve sergideki eserler hakkında fikir sahibi olur.

Sanat sergisindeki eserlerin önemini kavrar.

Gösterilen eserin sanatçısının adını bilgi dağarcığına katar.

Eserde gördüklerini açıklar.

Materyaller: Pastel boya, kağıt, makinelerin görsellerinin olduğu kartlar (Her bir drama çalışmasında toprak, ateş, hava su ve mekânizmalar bölümlerinden birbirine yakın olan iki bölümün kartlarını kullanılır.) 


\section{$\underline{\text { Isınma Calısmast }}$}

$\checkmark$ Çocuklar kendilerine bir eş bulurlar. Eş olan çocuklar makinelerin görsellerinin olduğu kartlardan bir tane alırlar (Şekil 8).

$\checkmark$ Çocuklar kendilerinde olan kartların eşini sergi salonunda konuldukları yerde bulup eşleştirirler. Kartı buldukları yerdeki makineyi incelerler. Makineyi kendi bedenlerini kullanarak oluştururlar. Oluşturulan makinler incelenir. Çocuklar bedenleri ile oluşturdukları makineye önce hareket, sonra ses eklerler (Şekil 9).

\section{Canlandirma}

$\checkmark$ Çocuklara "Sizce elinizdeki fotoğrafta olan makineyi kim yapmış olabilir?", "Bu makine ne ise yarıyor olabilir?", "Bu makineler tahtadan yapılmış, acaba neden tahtadan yapılmış olabilir?” gibi sorular sorulur. Çocuklar bu sorulardan yola çıarak fotoğraf kareleri oluştururlar.

$\checkmark$ Çocuklar istedikleri bir makinenin önüne giderler ve seçtikleri makinelerinin heykeli olurlar. Lider "Bu heykeller bir araya gelerek kocaman bir heykel olmak istiyorlar, ama heykelleri yapan kişi bu heykelleri birbirinden uzağa yapmış ve bir araya gelemiyorlarmış. Acaba bu heykeller nasıl bir araya gelebilir” der. Çocuklar heykellerin nasıl bir araya gelebileceğine yönelik çözüm önerileri bulurlar. Karar verdikleri bir çözüm önerisine yönelik doğaçlamalarını yaparlar (Şekil 10).

\section{Değerlendirme}

$\checkmark$ Çocuklar yaptıkları gezi ile ilgili resim yaparlar. Çocuklar yaptıkları resimleri arkadaşlarına anlatırlar.
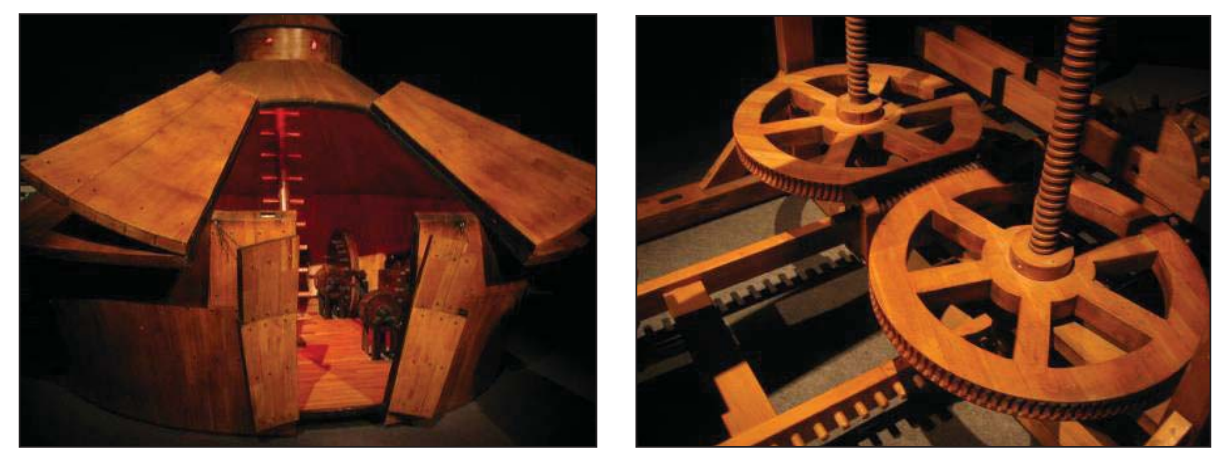

Şekil 8. Makinaların olduğu kartlar
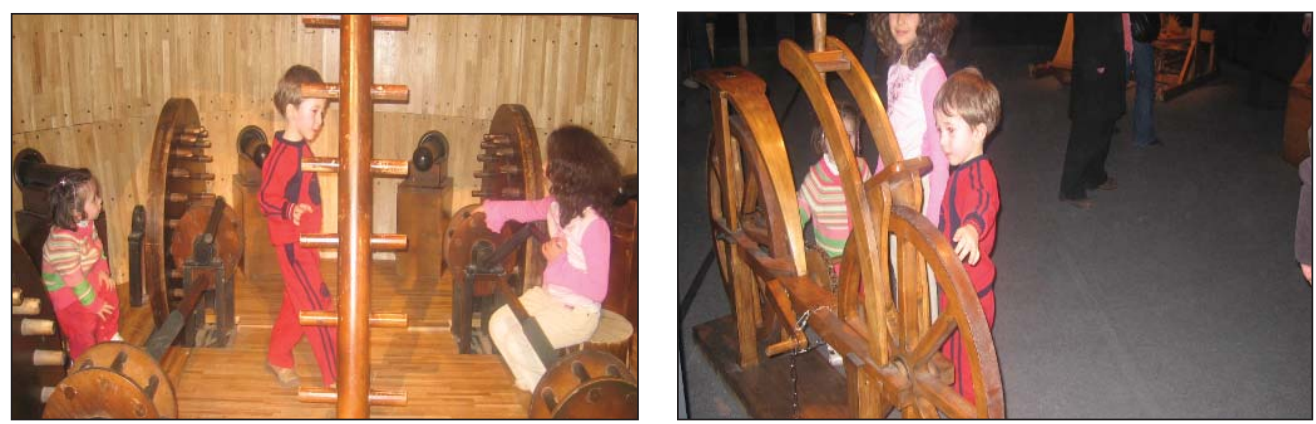

Şekil 9. Isınma çalışmaları 


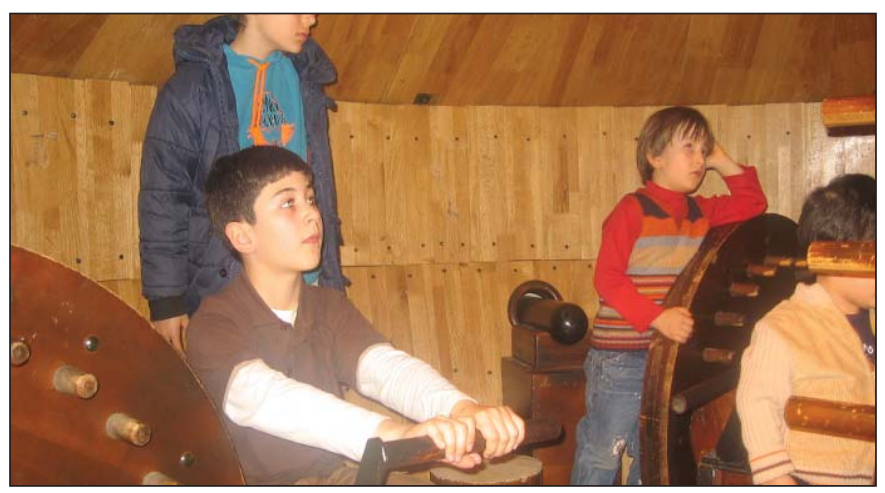

Şekil 10. Doğaçlama

\section{Drama çalışmaları}

Grup: Üçüncü ve daha üzerindeki sınıf düzeylerine devam eden çocuklar

\section{Kazanımlar:}

Sanat sergisi ve sergideki eserler hakkında fikir sahibi olur.

Sanat sergisindeki eserlerin önemini kavrar.

Gösterilen eserin sanatçısının adını bilgi dağarcı̆̆ına katar.

Üç boyutlu eserlere, farklı yönlerden bakıldığında değişik görünümleri olduğunu fark eder. Yapacağ1 görsel sanat çalışmalarında gösterilen eserlerden yararlanır.

Materyaller: Makinelerin görsellerinin olduğu kartlar, tüm çocukların aynı anda kullanabileceği büyüklükte bir kağıt, pastel boyalar.

\section{Isınma Calusmalart}

$\checkmark$ Çocuklarla sergi salonu girişinde buluşulur (Şekil 11). Her bir çocuk bu sergide en çok neyi görmek istediklerini sözleri kullanmadan hareketleri ile anlatırlar. İkili eşler oluşturulur; eşler Leonardo da Vinci'nin yapmış olduğu eserlerden birini belirleyip seçtikleri eseri heykel olarak gösterirler.

$\checkmark$ Mekânizmalar, toprak, su, hava ve ateşe ait görsellerin olduğu kartlar ayrı ayrı kutulara, kutular da sergi salonuna aralıklarla konur. Çocuklar beş grup oluşturup her bir grup bir kutunun yanına gider ve kutudan birer tane kart alırlar.

$\checkmark$ Gruplar ellerindeki kartlardaki makineleri incelerler, makinelerin ortak özelliklerini belirlerler. Belirledikleri ortak özelliklerden yola çıkarak bir öykü oluştururlar.

$\checkmark$ Gruplar öykülerini, öykünün son bölümünü olmadan canlandırırlar. Öykünün sonunu diğer gruplar yeniden oluştururlar.

\section{Canlandirma}

$\checkmark$ Çocuklardan ellerindeki karta ait olan makineyi sergide bulurlar. Aynı grupta olan çocuklar makineyi inceledikten sonra bir araya gelip, kendi inceledikleri makineyi arkadaşlarına anlatırlar. 
$\checkmark \quad$ Eserlerin Leaonado da Vinci'nin yapmadığı ancak onun çizimlerinden yararlanılarak yapıldı̆̆ı söylenir. Gruplar Leaonado da Vinci'nin çizimlerini yaptığı bu eserleri neden kendisinin yapmamış olabileceğini tartışırlar.

$\checkmark$ Gruplar Leaonado da Vinci’nin çizimlerini makinelere dönüştürmek istediği bir anın fotoğraf karesini oluştururlar. Fotoğraf kareleri incelenir. Sonra gruplar çizimlerin makineye dönüştürülmek istendiği anın sonrasında bir zamana ilişkin bir fotoğraf karesi oluştururlar. Fotoğraf karelerindeki karakterlere birer cümle belirlenir. Dokunulan kişi o an ile ilgili cümleyi söylerler.

$\checkmark$ Gruplar Leaonado da Vinci’nin şu anda bu sergide olsaydı neler yaşayabileceğine dair önemli bir anın fotoğraf karesini yaparlar. Bu anın öncesinde ve sonrasındaki sürece yönelik fotoğraf kareleri de oluşturulur. İlk fotoğraf karesinden başlayıp son fotoğraf karesinde bitecek şekilde doğaçlamalarını yaparlar.

\section{Değerlendirme}

$\checkmark$ Çocuklar büyük bir kağıdın üzerine makinelerin görsellerinin olduğu kartları yapıştırıp, boşluklara süreçte yaşadıklarına yönelik resim yaparlar. Kağıt uygun bir yere asılır, kağıttaki görseller ve resimlerden yola çıkarak çocuklar süreçte yaşadıkları ile ilgili düşüncelerini ve duygularının paylaşırlar.

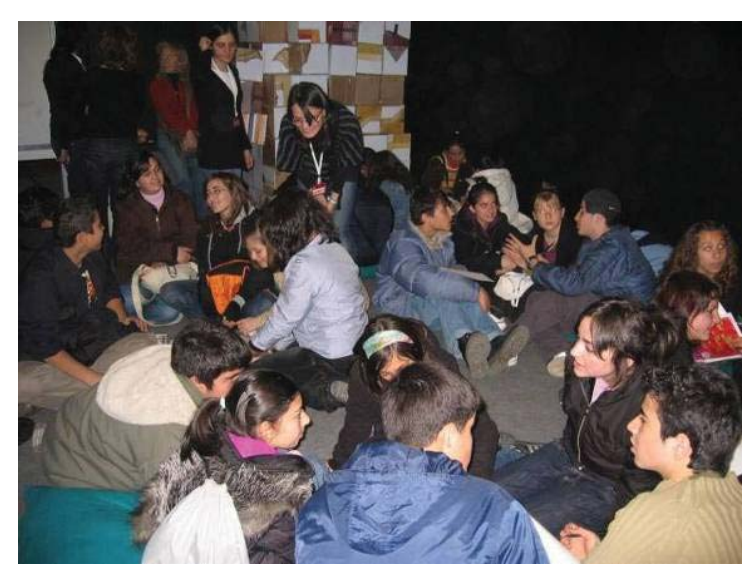

Şekil 11. Sergi salonuna girmeden önce sohbet

\section{Frig Kostümleri Tasarımı Projesi}

Anadolu Medeniyetleri Müzesi’nin 2008 yılında düzenlediği Frig Yılı etkinlikleri kapsamında hazırlanan Frig Kostümleri Tasarımı Projesi’nde, Ankara'da bulunan özel bir okulun öğrencilerinin de katılımı ile "Çocuklarla Frig Esintileri” temasıyla oluşturulmaya çalışılmıştır. Frig Uygarlı̆̆g ile günümüz arasında bağ kurmak, Frig Uygarlığı kıyafetleri ile Friglerin sosyal yapısı hakkında bilgi edinilmesi amaçlanmıştır. Frig kostümlerinin tasarlanması sürecinde dönemin giysileri kitaplardan, müzede sergilenen eserlerden yararlanılmış; profesyonel kostüm tasarımcıları ile Frig dönemi alan uzmanları birlikte çalışmışlardır. Döneme ait kral, kraliçe, Kibele, demonlar, askerler, kadın ve erkeklere yönelik tasarlanan kostümler proje grubunun okuluna gönderilmiş, gönüllü olan ve ailesinden izin alınan çocuklar farklı kostümleri deneyerek hangi kostümü giyeceklerine kendileri 
karar vermiştir. Daha sonra çocuklar Anadolu Medeniyetleri Müzesi'nde kostümlerini giyerek müzeler haftasındaki etkinliklere katılmışlardır. Üzeri açık otobüslerle Polatlı'ya gidilmiş, Gordion arkeolojik alanındaki Midas Tümülüsü ve Gordion Müzesi gezilmiş, müzenin bahçesinde açı etkinlikler yapılmış ve baharın gelişi, etkinliklere katılan yerel okulların öğrencileriyle bir şenlik halinde, Frig esintileri ile karşılanmıştır. Çocuklar müze ortamında, kostümleri ile drama çalışmalarına katılmışlardır. Gordion Müzesi’nde yapılan dram çalışması aşağıda verilmiştir.

\section{Drama Çalıșması}

Grup: Beşinci-altıncı sınıfa devam eden çocuklar

\section{Kazanımlar:}

Müzedeki eserlerle, bu eserlerin ait oldukları dönemler arasında ilişki kurar.

Eserler aracılığıyla Anadolu uygarlıklarını tanır.

Uzak ve yakın çevresindeki doğal ve tarihî güzellikleri tanır.

Materyaller: Frig kostümleri

\section{Isınma Calısmalart}

$\checkmark$ Çocuklar kostümlerine uygun rollere (kral, kraliçe, askerler vd) girerek müzeyi gezerler (Şekil 12).

$\checkmark$ Her çocuk Frigler döneminden ilgilerini çeken bir objeyi belirleyip, objenin olduğu yerde belirlediği obje ile neler yapıldığını hareketleri ile gösterir.

$\checkmark$ Çocuklar küçük gruplara ayrılırlar. Gruplardaki çocuklar kostümlerini giydikleri kişilerin rollerine girerek müze hakkında sohber ederler.

$\checkmark$ Başka kişilerle yeni gruplar oluşturulur. Frigler döneminde günlük yaşama yönelik canlandırmalar yapılır.

\section{Canlandirma}

$\checkmark$ Çocuklar gruplara ayrılırlar. Gruplara Frigler döneminde ardıç ağacının önemli olduğu, bu ağaçtan yapılan mobilyaların ününün dünyaya yayıldığı bilgisi çocuklarla paylaşı1ır.

$\checkmark$ Çocuklar Friglerler ile ilgili kitaplardan ardıç ağacı ve frig mobilyaları ile ilgili bilgileri incelerler.

$\checkmark$ Gruplar aşağıda verilen doğaçlamaları yaparlar.

- Büyük bir sipariş almış, ancak elinde yeterince ardıç ağacı kalmamış olan bir mobilya ustas1

- Tarihi eser olan ahşap bir masanın korunmasına yönelik çalışma yapan müze çalışanları

- Yüzyıllar sonra Gordion Müzesine gelen Frigler 


\section{Değerlendirme}

$\checkmark$ Çocuklar müzenin bahçesine çıkarlar. Çocuklar "bahar şenliğinde" olduklarını düşünerek kostümlerini giydikleri kişilerin rollerine girerler; hep birlikte bahar şenliğinde bir anın fotoğraf karesini oluştururlar. Fotoğraf karesinde kendi belirledikleri sıraya göre müzede geçirdikleri sürece yönelik birer cümle söylerler (Şekil 13).

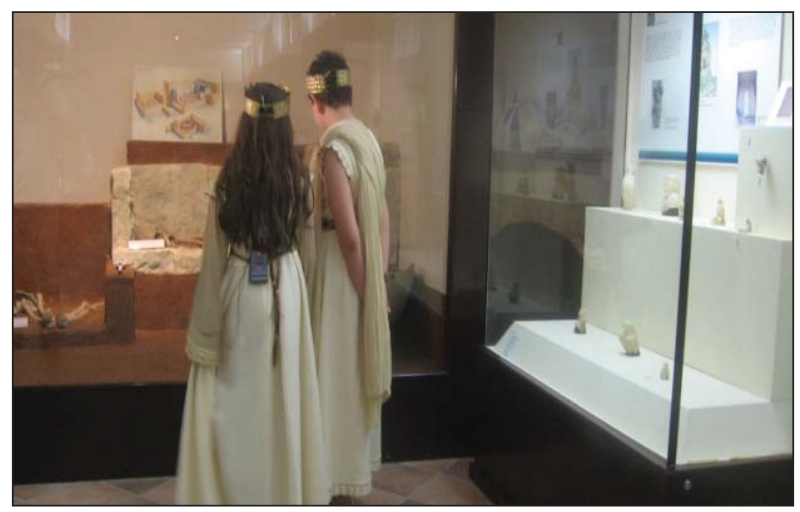

Şekil 12. Isınma çalışmaları

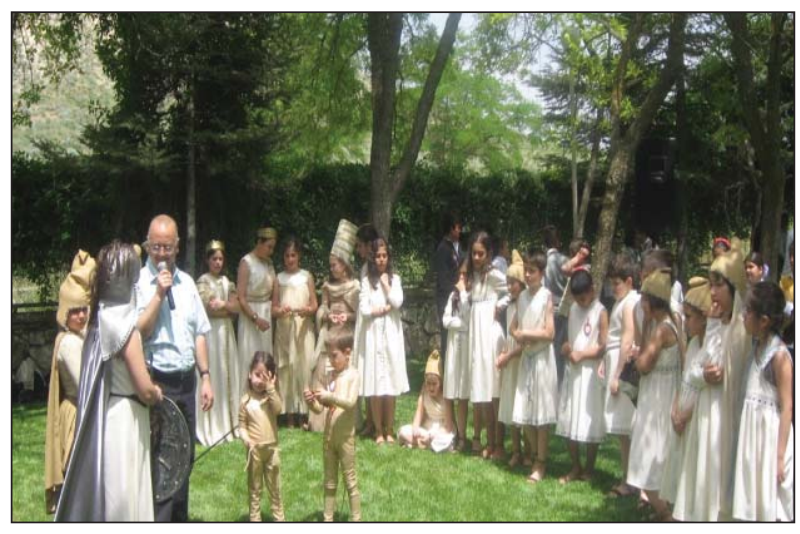

Şekil 13. Değerlendirme aşamast

\section{Kaunos Çocuk ve Arkeoloji Çalıştayı}

Kaunos, Köyceğiz sınırları içinde Dalyan'a yakın bir yerde bulunan antik bir kenttir. Kent bir mitosa göre Miletos'un ikiz çocuklarından biri olan Kaunos tarafından Karya-Likya sınırında kurulmuştur. Kaya mezarlarıyla Türkiye'nin en çok ilgi çeken ören yerlerinden biri olan Kaunos, ticari açıdan önemli bir liman kentiyken zamanla denizin alüvyonlarla dolmasıyla liman özelliğini kaybetmiştir. Sur duvarları, agora, çeşme, hamam, tiyatro ve tapınak kalıntıları Kaunos'un antik dönemde etkili bir kent olduğunu ortaya koymaktadır.

"Kaunos Yaz Sempozyumları" kapsamında, 16-20 Haziran 2012 tarihleri arasında "Çocuk ve Arkeoloji Çalıştayı" yapılmıştır. Bu çalışmaya 7-12 yaşlarında olan çocuklar dahil edilmiştir; Başkent Üniversitesi web sitesi üzerinden yapılan duyuruya başvuran çocuklar ile kazı evine yakın köyde yaşayan çocuklar katılmışlardır. Çalıştayda, çocuklara kültürel mirasının kendi geleceklerinin teminatı olduğu gerçeğini aşılamak ve kültürel mirasın korunmasına yönelik yapılması gerekenleri 
kendileriyle paylaşmaktır. Çalıştay süresince, çocuklar uzmanlardan dinleyecekleri kısa teorik bilgileri oyun, drama, pratik uygulamalar ile eğlenerek ve kendileri yaparak öğrenmişlerdir. Çalıştayda, antik çağda askerler, gladyatörler ve korsanlar, antik çağda günlük yaşam, antik çağda oyun ve oyuncaklar, antik çağda masallar, antik çağın ünlüleri gibi belirlenmiş olan günün temasına yönelik birer drama çalışması planlanmıştır. Örnek bir drama çalışması aşağıda sunulmuştur.

\section{Drama Çalışması}

Grup: İlkokula devam eden çocuklar

\section{Kazanımlar:}

Uzak çevresinde bulunan ören yeri, tarihî eser, anıt gibi yerlerin geçmişi hakkında ön bilgi edinir.

Uzak çevresinde bulunan ören yeri, tarihî eser, anıt gibi tarihi güzellikleri tanır.

Öykü, masal, anı gibi sanat türlerinden yararlanarak çalışmalar yapar.

Ören yeri, tarihî eser, anıtlar ve müzelerden yola çıkarak iki veya üç boyutlu görsel tasarımlar yapar.

Materyaller: Demeter ile ilgili mitolojinin yazılı olduğu kağıtlar ve kil

\section{$\underline{\text { Isınma Calısmalart }}$}

$\checkmark \quad$ Lider role girerek "Çocuklar burası bir kazı alanı, bu kazı alanından ben sorumluyum (Şekil 14). Ama kazının yapılabilmesi için farklı mesleklerden uzmanlara ihtiyacım var; aşçı, arkeolog, mimar, sanat tarihçi, restoratör, şoför vd. Eğer benimle çalışmak isterseniz beni ikna etmeniz gerekiyor, beni ikna ederseniz kazıda çalışabilirsiniz..." der.

$\checkmark$ Çocuklar önce ne olmak istediklerine karar verirler ve onun heykeli olurlar. Daha sonrada kazı başkanını ikna etmeye çalışırlar. Kazı başkanı kendisi ile görüşmeye gelen kişileri kabul eder. İkna edenler hemen istedikleri bir mekânda işlerini yapmaya başlarlar. İkna edemeyenler ise tekrar bir görüşme yapıp tekrar ikna etmeye çalışırlar. Tüm çocukların çalışmaya başlaması sağlanır.

$\checkmark$ Çocuklarla birlikte mekânda olan sandalye, faklı boyutlardaki örtüler vb eşyalardan yararlanılarak bir kazı alanı oluşturulur. Çocuklar kağıtlara kazı alanında olması gerektiğini düşündükleri şeylerin resimlerini de yapıp mekânda istedikleri yere koyarlar.

$\checkmark$ Çocuklar kazı alanında çalışan birisinin heykeli olurlar. Liderin yönergesi ile çalışmaya başlarlar. Lider müziği açtığında heykel olurlar, kapattığında uzmanlar kazı alanında çalışmaya başlarlar. Çocukların ilgisi doğrultusunda tekrar yapılır.

\section{Canlandırma/Doğaclama}

$\checkmark$ Çocuklar, bir gün önce Kazı başkanından dinledikleri Demeter ile ilgili mitoloji akıllarında kaldığı kadarı ile anlatırlar.

$\checkmark$ Mitolojinin tamamının yazılı olduğu kağıtlardan çocuklar birer tane alırlar ve okurlar. 
"Demeter, mitolojide tarımın, bereketin, mevsimlerin ve anne sevgisinin tanrıçasıdır. Demeter, insanlara buğdayl ekip ondan ekmek yapmayı ögretir. Demeter' in Zeus 'tan Persephone adında bir kızı olur. Mitolojide, ana-kız sembolüyle özdeşleşmişlerdir. Persephone büyüdükten sonra, yer altı ve ölüler ülkesinin tanrısı Hades ona aşık olur. Bir gün Persephone arkadaşları ile tarlada çiçek toplarken çayır birden ikiye yarılır ve yeraltı tanrısı Hades, yeryüzüne çıkar. Aşık olduğu Persephone'yi yeraltına kaçırır. İnanışa göre ölüler ülkesinde bir şey yiyen bir daha oradan çıkamaz. Persphone'nin orada kalabilmesi için ona bir nar tanesi verir. Persephone'de hevesine yenik düşer ve bir nar tanesi yer. Demeter kızını aramak için yollara düşer ancak onu hiçbir yerde bulamaz. Üzüntüsü öyle büyük olur ki hayata küser. Sonunda her şeyi gören ve bilen güneş tanrısı Helios ona kızının yer altına kaçırlldığını söyler. Bunun üzerine Demeter Olympos 'tan kaçar, yüreği sızlayarak ussız bir yere çekilir. Onun küsmesiyle toprağın bereketi kalmaz, kitlık başlar. Zeus Tanrıça Demeter'e yalvarır. Ancak Demeter bir türlü ikna olmaz. Yalvarmalarının boşa gittiğini gören Zeus, en sonunda Persephone'nin yllın üçte ikisini yani çiçek açma ve meyve verme zamanını, anası Demeter'in, geri kalan üçte birini, yani kışı da kocası Hades'in yanında geçirmesini kararlaştırır. Demeter kızını bir domuz yavrusunun ona yol göstermesiyle bulur. Persephone her yeryüzüne çıtkğgnda, Demeter yeryüzüne baharı getirir. Böylelikle katllk biter ve bereket gelir toprağa”.

$\checkmark$ Çocuklar mitolojideki karakterlerin adlarının yazılı olduğu kağıtlardan birer tane alırlar. Çocuklar kağıtlarında yazılı olan karakterin rolüne girerek kazı evini gezerler. Gezmeleri bitince aynı karakteri tercih eden çocuklar bir araya gelerek grup oluştururlar.

$\checkmark$ Gruplar Demeter'in kızını bulması için ona yardımcı olabilecek yeni öneriler belirlerler. Belirledikleri öneri ya da önerilerden yola çıkarak doğaçlamalarını yaparlar.

\section{Değerlendirme}

Çocuklar süreçte yaşadıklarına yönelik kilden heykeller ya da resim yaparlar. Yaptıkları heykelleri ve resimleri arkadaşlarına anlatırlar (Şekil 15).

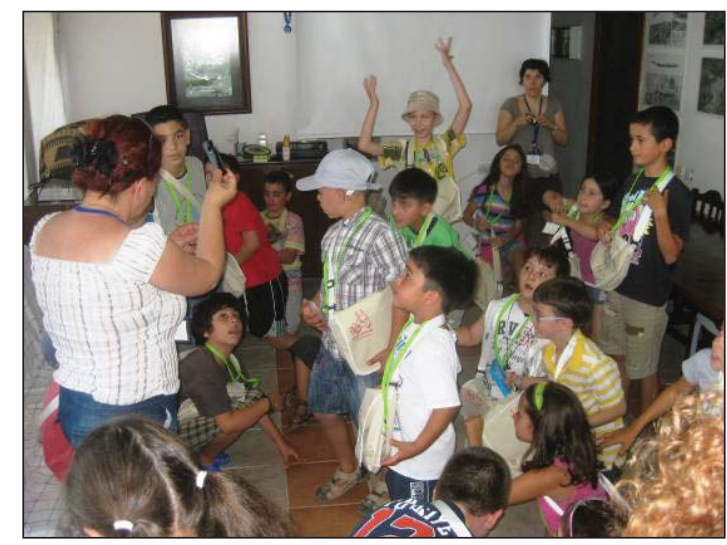

Şekil 14. Isınma çalışmaları 

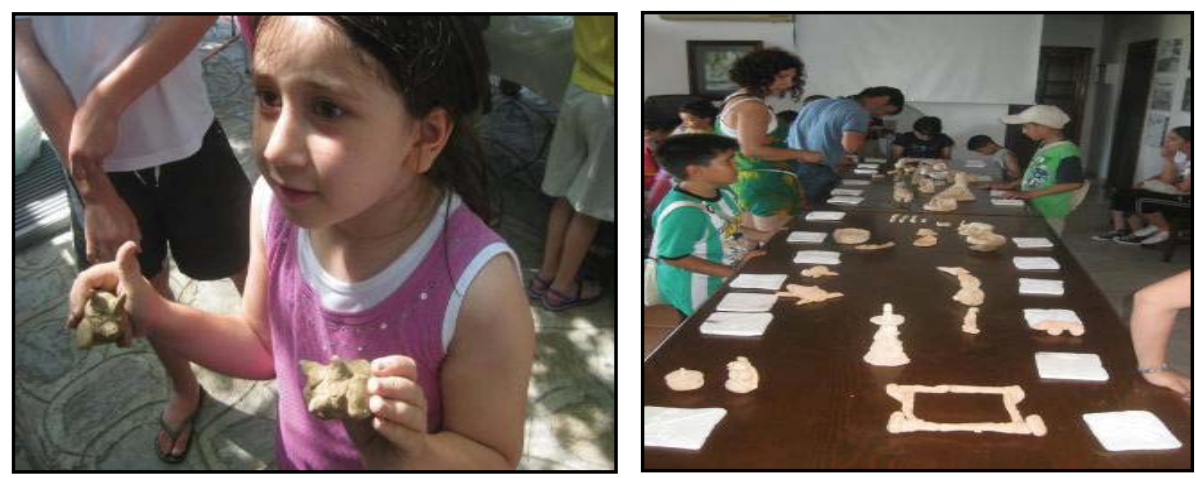

Şekil 15. Değerlendirme aşaması

$\mathrm{Bu}$ çalışmada müzelerde, arkeolojik alanlarda ve bir sergide yapılan drama çalışmalarına yer verilmiştir. Bizlere geçmişi anlatan mekânlarda yapılan her bir çalışmanın çocuklara sağladığı kazanımlar oldukça önemlidir. Tarihi mekânlarda yapılan çalışmaların yaygınlaştırılması ile daha fazla çocuğun benzer kazanımlara ulaşması sağlanabilir. Okullarda dört duvar arasında işlenen derslerde didaktik bir yöntemle işlenen konuların çok da akılda kalıcı olmadığı dikkate alındığında gerçek mekânlarda drama gibi yaşayarak yaparak edinilen kazanımların değeri büyüktür.

\section{Sonuç ve Öneriler}

Müzelerde ve arkeolojik alanlarda çocuklarla yapılan her bir çalışmanın önemin yadsınamaz. Soyut olan geçmişi çocuklara anlatmada gerçek mekânlarda, geçmişten günümüze kadar ulaşan gerçek objelerle çocukları buluşturmak, onların tarihi anlamalarını çok daha kolaylaştıracaktır. Drama gibi çocukların aktif katılımlarını sağlayan yöntemlerin kullanılmasıyla da çocuklar bu alanlarda yaşadıkları süreçte bir taraftan eğlenirken bir taraftan da öğrenmeleri anlamlı olacaktır. Bu nedenle müzeler, arkeolojik alanlar ve geçmişi anlatan sergiler gibi farklı mekânlarda çocuklara yönelik eğitim etkinliklerinin düzenlemesi önemlidir. Bu etkinlikleri planlarken disiplinler arası bir anlayışla ilgili meslek elemanları ile işbirliği içinde olunmalıdır; eğitimci, drama lideri, müze çalışanları, arkeolog, sanat tarihçileri, Anadolu uygarlıkları ve mitolojisi alanında çalışan uzmanlar, tasarımcılar çocukların üstün yararı açısından disiplinler arası bir anlayış ile birlikte çalışıp yeni projeler geliştirebilirler. Çocukların tarihi mekânlarda aktif katılımları ile yapılan eğitim etkinliklerinin yanı sıra, çocukların kendi başlarına çalışabilecekleri didaktik anlayıştan uzak ıraksak düşünce ile hazırlanmış kitaplar, tarihi ve sanat eserlerine yönelik basıl1/görsel/interaktif eğitim materyalleri, tarihi ve sanat eserlerine yönelik planlanmış sanat etkinlikleri gibi materyaller geliştirilerek çocuklara sunulabilir. Böylece uzaklarda olan tarihi mekânlar, ören yerleri, müzeler, tarihi ve sanat eserleri çocukları da içine almış olur. 


\section{Kaynakça}

Adıgüzel, H. Ö. (2010). Eğitimde yaratıcı drama. Ankara: Nobel Yayıncılık

Akyol, A. A. (2003). Müze ve galerilerin eğitim işlevleri. Evrensel Kültür Dergisi, 140, 71-73.

Akyol, A. A. (2006). Müzecilikte bir müze: Anadolu Medeniyetleri Müzesi. Çoluk Çocuk Dergisi, 62(11), 58-59.

Akyol, A. A., Koman, E., Baysuğ, A., Yılmaz, M. O., Thomas-Özel, C.ve Demirdelen, H. (2004). Anadolu Medeniyetleri Müzesi eğitim seksiyonu projesi. M. Artar. (Ed.), IV. Ulusal Çocuk Kültürü Kongresi (437446). Ankara: Çocuk Kültürü Araştırma ve Uygulama Merkezi (ÇOKAUM).

Akyol, A. A. ve Köksal Akyol, A. (2005). Arkeolojik alanda drama: Magnesia örneği.7. Drama Liderleri Buluşmast ve Ulusal Drama Semineri, Dramada Araylşlar (47-58). Ankara: Oluşum.

Akyol, A. A. ve Alpagut, A. (2012). Educational projects for the children at anatolian civilization museum between the years 2002-2008. Journal of Procedia- Social and Behavioral Sciences, 51(2012), 1087-1096.

Akyol, A. A., Paykoç, F., Dizdar Terwiel, C., Köksal Akyol, A., Aslan, N., Gürçay, B. ve Denizli, H. (2012). Çocuk ve tarih dostu kitaplar: Senden Önce Anadolu Projesi Eğitim Kitapları. 3. Ulusal Çocuk ve Gençlik Edebiyatı Semроzуити (171-179). Ankara: Ankara Üniversitesi Çocuk ve Gençlik Edebiyatı Uygulama ve Araştırma Merkezi (ÇOGEM).

Akyol, A. A., Köseoğlu, S., Türkay, B. C., Kıdıman, E. ve Özkan, H. (2015). Yasemin Karakaya Science and Art Center Archaeology Project, Global Journal on Humanites \& Social Sciences, 2015: Vol 1, No: 1, 453-461.

Akyol, A. A. (2016). Alternatif Eğitim Ortamı Olarak Müzeler: Anadolu Medeniyetleri Müzesi Eğitim Projeleri. Ankara Üniversitesi Geliştirme Vakfi Özel Okulları ANKÜ Gelişen Öğrenci Gelişen Öğretmen Sempozyити Bildiriler Kitabı (41-60). Yayın No: 1.

Alevcan, S. (2005). Drama uygulamaları, belirli gün ve haftalar için. İstanbul: Ya-Pa Yayın Pazarlama San. ve Tic. A.Ş.

Artut, K. (2009). Sanat ĕgitimi kuramlarl ve yöntemleri. Ankara: Anı.

Atagök, T. (1982). Çağdaş müzecilik kavramı doğrultusunda türk sanat müzelerini kültürel etkinliklerini saptanması. Yayınlanmamış yeterlilik tezi, Mimar Sinan Üniversitesi, İstanbul.

Bingöl, I. (2004). Çocuk gözü ile Magnesia. İstanbul: Homer Yayıncılık.

Bingöl, I. ve Bingöl, O. (2014). Through the eyes of children. Ankara: Bilgin Kültür Sanat.

Buyurgan, S. ve Mercin, L. (2005). Görsel sanatlar eğitiminde müze eğitimi ve uygulamaları. V. Özsoy (Ed.), Ankara: Görsel Sanatlar Eğitimi ve Derneği Yayınları: 2, Varan Matbaacılık.

Can Yaşar, M. (2013). Drama. Okul Öncesi Öğretmenliği. N. Aral, Ü. Deniz ve A. Kan (Ed.). (399-425). Ankara: Alan Bilgisi Yayınları.

Çocuk Çalıştayı, (2012).http://cocukcalistayi2012.baskent.edu.tr/, 12.04.2017.

Çorum Müzesi, (2011). http://www.corum-muzesi-cocuk-egitim-atolyesi-etkinlikleri.html, 12.04.2017.

Dalbudak Pekdemir, Z. ve Köksal Akyol, A. (2015). Examination of the effect of drama education on multiple intelligence domains of children attending to 5th grade. Education and Science, 40 (182), 143-158.

Demirdelen, H. (2003). Müze eğitimi uygulamaları. Anadolu Medeniyetleri Müzesi 2002 yılllğg. XVII, 331341. Ankara: Dönmez Offset.

Denizli, H., Alpagut, A., Demirdelen, H., Metin, M., Demirtaş, N. ve Akyol, A. A. (2006). Anadolu Medeniyetleri Müzesi 2005-2006 yılı eğitim etkinlikleri, müze eğitim atölyesi, III. Müze Çocuk Şenliği ve Roma Hamamı I. Çocuk Olimpiyatları. Anadolu Medeniyetleri Müzesi 2005 Ylllığı, XIX, 35-85. Ankara: DÖSIM.

Denizli, H., Tırpan, N., Demirtaş, N., Alpagut, A., Demirdelen, H., Metin, M., Geleri, C., Çelik, T., Gündüz, U., Günay, S., Yıldız, B.ve Bayram, S. (2007). Anadolu Medeniyetleri Müzesi 2006-2007 y1l eğitim etkinlikleri, müze eğitim atölyesi, IV. Çocuk Şenliği ve II. Çocuk Olimpiyatları. Anadolu Medeniyetleri Müzesi 2006 Ylllı̆gl, XX, 35-87. Ankara: DÖSIM. 
Fazlığlu, Y. ve Fazlıŏlu, İ. (2009). Erken çocuklukta müze ve eğitim. Y. Fazlıŏlu (Ed.), Erken Çocukluk Gelişimi ve Eğitimi (325-340). İstanbul: Kriter.

Hein, G.E. (1998). Learning in the museum. London: Routledge.

Hui, A. and Lau, S. (2006). Drama education: a touch of the creative mind and communicative express in veability of elementary school children in Hong Kong. Thinking Skills and Creatvity, 1(2006): 34-40.

Kandır, A. (2003). Yaratıcı dramanın okul öncesi eğitim planındaki yeri ve hedefleri. Okul Öncesi Eğitimde Drama Teoriden Uygulamaya (3. baskı). Ankara: Kök Yayıncılık.

Köksal Akyol, A. ve Akyol, A.A. (2014). Her Yönüyle Okul Öncesi Eğitim-Okul Öncesinde Görsel Sanat Eğitimi, "Okul Öncesi Eğitimde Müzeler", (Ed. İlkay Ulutaş), Ankara: Hedef CS Yayıncılık ve Mühendislik, Cilt 2, 275-291.

Köksal Akyol, A. (2014). Drama in Preschool Education. Preschool Education in Turkey and in the World: A Theorical and Empirical Perspective. (Ed.) M. Taner Derman, H. A. Başal, E. Ömeroğlu, Z.Kostova, 4453. St. Kliment Ohridski University Press. Sofia.

Köksal Akyol, A. ve Akyol, A. A. (2015). Museums and early childhood education. Global Journal on Humanites and Social Sciences, 1, 101-108.

Mardin Müzesi (2010). http://www.mardinmuzesi.gov.tr/mardinmuzesi/detay.asp? id=96\&kategori=ATÖLYE; 12.04.2017.

Mc Caslin, N. (2006). Creative drama in the classroom and beyond. America: United States of Pearson Education.

Onur, B. (2008). Çocuk müzeleri ve müze eğitimi. Ankara: Ürün.

Özbek, G. (2016). Alternatif mekânlarda drama. S. Erdoğan (Ed.), Çocuk ve Drama. s. 102-125. Eskişehir: Anadolu Üniversitesi.

Paykoç, F. (2011). Müzede drama. A. Köksal Akyol (Ed.), İlköğretimde Drama. İstanbul: Kriter Yayınları.

Paykoç, F. ve Baykal, S. (2000). Müze pedagojisi: Kültür, iletişim ve aktif öğrenme ortamı olarak müzelerin etkinliğine ilişkin bir çalışma. Müzecilikte yeni yaklaşımlar küreselleşme ve yerelleşme. 3. Uluslararası Tarih Kongresi, (102-113), İstanbul: Numune.

Szecsi, T. (2008). Creative Drama in Preschool Curriculum: Teaching Strategies Implemented in Hungary. Child Education, 85(2), 120.

Tezcan Akahmet, K. (2001). Müze ortamında öğrenme ve drama. N. Aslan (Ed.), Drama ve Müze Pedagojisi. Oluşum Drama Enstitüsü Yayınları, Ankara: Fersa.

Wright, P. R. (2006). Drama Education and Development of self: Myth or Reality?, Social Psychology of Education, 9: 43-65.

Yetimoğlu, S. ve Akyol, A. A. (2013). Medical and Health Museums in Turkey and Educational Activities. European Conference on Social Science Research (IASSR) European Journal of Research on Education, Special Issue: Art in Education, 16-24. 